\title{
Marx, Materialism and the Brain: Determination in the Last Instance?
}

\author{
Joss Hands \\ Newcastle University, Newcastle upon Tyne, UK, joss.hands@ncl.ac.uk, \\ http://www.ncl.ac.uk/sacs/staff/profile/josshands.html
}

\begin{abstract}
It is well acknowledged that there is not one but many Marxes, and one area where this has been most evident is in the question of technological and economic determinism. This article traces some key moments in this debate and attempts to locate their most recent iteration in disagreements over the place of the human brain in both historical agency and value creation in so called 'cognitive' or 'post-Fordist' capitalism. Of significant interest in the current configuration - or rather composition - of capital is the place of the digitisation of the labour process and its relation to, and integration with, human cognition and volition. Arguments over the attention economy and the power of post-Fordist capitalism to distract and direct is a significant variation of the question of ideology and the latest variation of the base/superstructure debate. This article will unpack the aforesaid issues to offer an articulated perspective in order to make the argument that taking a balanced view of determination will allow us to acknowledge that - drawing on the argument of determination in the last instance - we can hold both of these 'Marxes' to be simultaneously valid. Here, a revisiting of Marx's concept of General Intellect will be undertaken, wherein the productive capacity of living labour is employed in both active agency and the capture of value, in which the plasticity of the living brain becomes the pivot point for both exploitation by, and resistance to, capital.
\end{abstract}

Keywords: brain, consciousness, digital labour, intention, autonomous Marxism, base, superstructure, determinism, plasticity

\section{Introduction}

We live in a time of climate catastrophe, infrastructure collapse, appalling social deprivation and hardship. Generations born in even the most prosperous countries have little hope of reaching the same standard of life as their parents. Yet never in history has there been such wealth, such astonishing accumulations of money, goods and opportunity. The technological wonders of the 21 st century render the needs of physical labour and want an unnecessary burden, yet still the misery, the soul-destroying brutality of this world, expands without seeming limit. Mechanisation and digitalisation of the economy, instead of liberating the time of workers towards the cultivation of free expression and self-development, has merely shifted the contradictions of capitalism onto the terrain of the human brain. As such the brain can now be regarded as the key organ of capitalist production. The aim here is thus to survey some of the perspectives that inform this shift and to open up a space for further reflection, and in particular to explore how this pertains to questions of determinism and the relation of base to superstructure.

Much of this trajectory is entirely explicable within the writing of Karl Marx as the unfolding of the logic of capitalism. Yet one question remains stubbornly unanswered - why does capitalism persist? In the 200 years since the birth of Karl Marx such 
questions have been raised and debated repeatedly. The fact that we still turn to Marx for answers is testament to the enduring power of his ideas.

It is well recognised that there are many Marxes, and a multitude of Marxisms, so we need to ask: which Marx should we be turn to? Étienne Balibar $(2017,4)$ tells us that, "Marx was not led by his theoretical activity towards a unified system, but to an at least potential plurality of doctrines which has left his readers and successors in something of a quandary". However, Balibar also sees this as a distinct advantage, which springs from the openness of Marx's method. One area of ambiguity, and one that is of direct relevance here, is the alleged 'break'. The 'break' occurred somewhere between The Economic and Philosophical Manuscripts of 1844 and The German Ideology. Louis Althusser $(2017,4)$, the leading proponent of such, placed this in 1845. The break is alleged between a humanistic Marx - still influenced by the idealism of Hegel and attached to a view of the human as torn between an authentic self-determined species-being and the alienation of labour - and the post-break Marx, who was committed to understanding the human in the context of the scientific unfolding of history and the internal contradictory economistic logic of capital.

This matters because it concerns the question of where to place the human being, and the human brain, in the chain of determination. The answer leads to very different proposals as to what we are to do in order to bring about change. In the crudest terms: do we marshal our collective intelligence to force change, or do we stand by at the ready to let capital destroy itself and harness the inevitable unfolding of communism?

Balibar agrees that there is undoubtedly such a break, but that there is more than one such break, and these breaks are as much to do with adaptations to historical shifts and events as a complete abandonment of early naive positions. For example, the failure of the revolutions of 1848 was just as significant as 1845 (Balibar 2017, 9). Thus, the case can be made for Marx as a reactive and flexible thinker whose ideas can and should be reviewed and reapplied to different historical moments, and as such his continuing value is in this flexibility.

It is perhaps then helpful to offer a clarification here, a simplistic but useful distinction between four orientations to Marx: firstly, an orthodox rigidly deterministic reading rooted only in the economic writings; secondly, a recognition of the humanistic early Marx but the positing of a clear break, with a commitment to the 'mature' postbreak Marx, in which a purely 'scientific socialism' is maintained; thirdly, a downplaying of the break, in which the humanism of the early Marx is present throughout his later works; finally an orientation that recognises the fundamental importance of the economic, but which recognises the multiplicity of Marxes and that a balanced view of the whole Marx is necessary.

It is this final position that I shall be working towards in the article, via an address to the other three. The connecting factor is the need to recognise the significance in each approach of the consequences towards our understanding of the place of the brain, consciousness, and as such agency. I will go on to argue that in our current configuration of capitalism it is over the brain that the struggle is at its most intense and where the stakes are highest.

\section{Orthodox Marxism}

The orthodox interpretation, or more pejoratively known as 'Vulgar Marxism' is represented by the writings of, for example, Stalin, Kautsky, and Plekhanov. Orthodox Marxism is characterised by Erik Olin Wright as a, "highly deterministic version of historical materialism", in which, "human history was held to follow a well-defined tra- 
jectory of stages, driven by the development of the forces of production (roughly, technological capacity) and their interactions with relations of production (roughly, real property relations)" (Wright, Levine and Sober 1992, 11).

The source of much of this interpretation comes from one of the most famous statements of Marx, "The mode of production of material life conditions the general process of social, political and intellectual life. It is not the consciousness of men that determines their existence, but their social existence that determines their consciousness" (Marx 1987, 263).

Such a view is rigidly reproduced by Joseph Stalin and expressed in the text, Dialectical and Historical Materialism, which became the orthodoxy of the 2nd International. Stalin tells us that "Marx's philosophical materialism holds that the world is by its very nature material [...] and that the world develops in accordance with the laws of movement of matter" (Stalin 1938). Such a narrow interpretation tends towards a clockwork version of materialism and of dialectics. Stalin also makes a number of inferences from this position regarding consciousness and the brain. He states that consciousness is simply an epiphenomenon resulting in a derivative form from the brain, as the material substrate of thought, and by inference is fully determined by its relation to its material situation: "consciousness is secondary, derivative, since it is a reflection of matter, a reflection of being; that thought is a product of matter which in its development has reached a high degree of perfection, namely, of the brain, and the brain is the organ of thought" (Ibid.). This position is one that Stalin draws on from Lenin, citing Lenin's claim that "Consciousness is only the reflection of being, at best an approximately true (adequate, perfectly exact) reflection of it" (Ibid.).

This is a situation in which the mental and spiritual life of a society is entirely secondary to its material conditions and Stalin is unambiguous in this claim: "Whatever is the being of a society, whatever are the conditions of material life of a society, such are the ideas, theories political views and political institutions of that society". By placing the brain as coterminous with the base, and the mind as a secondary offshoot, akin to an aspect of the superstructure, it renders agency nothing but a submission of consciousness to the logic of history. This is both a socially, but also scientifically, naïve reading of the capacity of the brain and is in line with a view of the worker as utterly subsumed within capital, and in need of salvation by the insights of a vanguard with the insight track to history.

\section{Structural Marxism}

Such views are now widely dismissed as overly crude and deterministic. An alternative approach, that still maintains a commitment to a 'science' based approach, is characterised as the second position offered above, and can be broadly captured by the idea of 'relative determinism'. Relative determinism states that there is a definite determinate course, maintaining a distinction from the 'voluntarist' strain of Maoist thought, that John Molyneux has characterised as "absolute indeterminism", and which posits "the idea that human beings can do whatever they want without constraint" (Molyneux 1995) and which is arguable no Marxism at all, and is also a naïve assumption in relation the brain's plasticity (see Section 6 for more).

Relative determinism offers a compromise position that there are determining conditions, but these do not constitute a fatalistic absolutism. In this scenario a chosen course of action can push towards one or another outcome that is not inevitable. Again, Molyneux argues that "If in a given situation a particular desired outcome is either probable but not guaranteed or hangs in the balance, then every action taken 
towards that outcome (provided, of course, it is not counterproductive) increases the probability of it occurring and is therefore valuable" (Molyneux 1995).

Relative determination is broadly the 'democratic centrist' or Trotskyist position, in which history "hangs in the balance between strongly determined alternatives" (Ibid.) and is only marginally variable from the Stalinist position. Crucially it states that "in every concrete situation there is a definite limit on what we by our conscious action can achieve" (Ibid.). Again, the worker is reduced to a reliance on a cadre gifted with the capacity to discern the direction of history, and when the moment is ripe nudge it in the right direction. The brain in this scenario is ether seen as a passive aspect of fixed capital, or in the cadre becomes a consequentialist calculation machine.

A more nuanced variation of this position is the idea of determinism in the last instance, wherein there are multiple factors as play in any situation that produces an 'overdetermined' trajectory. Such a view has its roots in the structural Marxism of Louis Althusser, and it was adopted and reframed within the tradition of British Cultural Studies precisely as a way of rebalancing and reconceptualising the 'base/superstructure' division.

Stuart Hall explores the ways in the base/superstructure metaphor needs to be re-thought and asks, "can we think this problem in such a way as to retain a key premise of historical materialism: the premise of 'determination in the last instance' by what is sometimes misleading re-referred to as 'the economic'?" (Hall 1977, 44). The important point being the retention of 'historical materialism' which comes under question when there is a drift towards the position of the "absolute autonomy" of the superstructure from base, which the purely voluntarist traditions tends towards. Hall argues that "Marx had established that the economy is determinant in the last instance, but that the superstructures had their own 'affectivity', which could not be simply reduced to the base" (Ibid., 53). Hall is drawn towards Althusser's structural Marxism as a way of accounting for this tension, and while by no means accepting it in its entirety but does import the 'decentring of the subject'. Hall is not without scepticism, but in the end believes, it is an "extremely weak but useful conceptualisation", yet Hall $(2016,110)$ is "not disposed to give it up". This implies some autonomy in the brain's capacity to absorb and reframe a situation, but in this still loosely Althusserian understanding of subjectivity it is placed in the, again, subordinate structural relation to its ideological situation - it's real conditions of existence being only accessible through officially sanctioned means, contrary to current scientific understanding of brain plasticity (see Section 6).

Ellen Meiksins Wood is much less forgiving of Althusser; with the aspects of the decentring of the subject being of particular concern, she describes Althusser's achievement as having "redefined the relations between base and superstructure in such a way that the vagaries of human agency could be 'rigorously' excluded from the science of society, insisting on completely 'structural' determinations, while at the same time allowing for the unpredictable specificity of historical reality" (Meiksins Wood 1995, 50). The withering reading is intensified when she makes the point that Althusser "did little to shift the terms of Marxist theoretical debate decisively away from the terrain established by Stalinist orthodoxy. The base/superstructure model retained its mechanical character and its conceptualisation of social structure in terms of discrete, discontinuous, externally related 'factors', 'levels' or 'instances'” (Meiksins Wood 1995, 51).

With regard to 'levels', we find ourselves in familiar territory as to the place of the brain. Here the brain is judged as a subsumed element of the base, albeit somewhat less directly, through the process of submission to the ideological state apparatuses. 
Although these are deemed to be relatively autonomous there is almost no scope for autonomy within the process of interpellation.

\section{Humanist Marxism}

There is thus one concept, or rather capacity, which all these positons leave out indeed actively undermine - that of will, volition or to use Raymond William's term, 'intention'. Such is the third, humanist oriented, position referred to above. Such an orientation is taken by Erich Fromm (2004) or Norman Geras (1983), who insist on Marx's commitment to a human nature that is open, creative and agental. But here I would also place, perhaps problematically but unapologetically, Raymond Williams (2005). In his essay on base and superstructure, amongst a number of his other writings, Williams attempts to reinforce the fundamental importance of intention, no doubt at risk of accusations of volunteerism. Williams explicitly attempts to recognise the base/superstructure relation as neither dissolvable into a completely totalising whole, nor divisible into a set of discreet autonomous levels. As such Williams argues that, "when we talk of 'the base' we are talking of a process and not a state", meaning that "[w]e have to revalue 'determination' towards the setting of limits and the exertion of pressure" (Williams 2005, 34). As such, he certainly argues against a stark distinction of base and superstructure, recognising, with Lukács, that a notion of totality can be "compatible with the notion of social being determining consciousness" (Ibid.). But Williams believes that totality can be an empty concept if we just have interacting forces, hence the question of what is determining what becomes overly complex and opaque. As such "the key question to ask about any notion of totality in cultural theory is this: whether the notion of totality includes the notion of intention" (Williams 2005, 36). Williams invokes a rather unclear use of 'intention' which echoes a somewhat ambiguous use elsewhere in his writing. However, he is clear that intention is not an individual or simple expression of a choice or rationale, pertaining to a specific decision, but rather a social entity. Williams explains that "any society has a specific organisation, a specific structure, and that the principles of this organisation and structure can be seen as directly related to certain social intentions, intentions by which we define the society" (Ibid.).

A social intention then is an active force that contributes to an understanding of the totality of a situation and that, to an extent, determines it. The fact that Williams wishes to remain true to a Marxist positon means he is not prepared to grasp such intention as arbitrarily arrived at, but always out of a concrete set of circumstances. This echoes one of the most frequently cited of Marx's statements, "Men make their own history, but they do not make it just as they please; they do not make it under circumstances chosen by themselves, but under circumstances directly encountered, given and transmitted from the past" (Marx 1979, 103). As such Williams also links intention to the idea of hegemony: "Indeed I think that we can properly use the notion of totality only when we combine it with that other crucial Marxist concept of 'hegemony"' (Williams 2005, 37). This is not a surface ideology but a practice which "saturates the society" and which "emphasises the facts of domination" (Ibid.).

This reminds us of the need to comprehend how such saturation continues to occur, in order to combat it. As such there is a compelling case for developing the understanding of intention further, beyond the science that was available to Williams the time, and in light of the digital revolution and the continuing intensification of PostFordism. 


\section{Autonomist Marxism}

This idea of the centrality of intention as a determining factor brings us to another strand of Marxism, born of the Italian Autonomist movement, and which has been operative in reframing Marxism around working class movements as the driving force of capitalist development - but taking into account the post-structuralist critiques of humanism and shifts in subjectivity associated with the move to Post-Fordism which reflects the fourth position offered above. It also brings us into contact with another of Marx's important writings that have added to the richness of base/superstructure debates and which unambiguously reemphasis the importance of Marx for today, that is the so called 'Fragment on Machines' in the Grundrisse (Marx 1973, 690-712).

There is a very fruitful resonance between the developments in Autonomous Marxism and the humanistic strand of British Cultural Studies mentioned above. This is one that offers a way to draw out the significance of Marx for the current social and technological configuration of capitalism that emphasises an understanding of the brain as a productive and active force, without reverting to an essentialist conception of human nature. For the Autonomists Marx's notion of 'general intellect' is of primary importance, in that regard it is worth quoting Marx's in full:

Nature builds no machines, no locomotives, railways, electric telegraphs, self-acting mules etc. These are products of human industry; natural material transformed into organs of the human will over nature, or of human participation in nature. They are organs of the human brain, created by the human hand; the power of knowledge, objectified. The development of fixed capital indicates to what degree general social knowledge has become a direct force of production, and to what degree, hence, the conditions of the process of social life itself have come under the control of the general intellect and been transformed in accordance with it. (Marx 1973, 706)

There are few more direct indications of the significance of the brain in Marx's writings. This certainly cannot be put down to be part of his 'early' 'humanistic' phase, given its estimated authorship is around 1857, at least 12 years after the 'break'. Here it is the human brain and human collective will that are the determinate features, of course there could be a temptation here to claim this as direct support for a voluntarist conception, and another full reversal of the line of determination, something that can, according to the key Autonomist thinker Paolo Virno, "hardly be called a 'Marxian' thesis" (Virno n.d.). However, this would be a naïve position and one should read Virno's point as a somewhat ironic jab at orthodox readings of Marx. In fact, Marx is clear in the fragment that the general intellect is no sooner recognised than it is subsumed. It is the ever-increasing sophistication of machinery that threatens to absorb the collective skills and knowledge of living labour into fixed capital (dead labour), this is a parallel shift from the formal to the real subsumption, that is the move from artisanal pre-capitalist labour, parasitically captured by capital, to a fully developed factory system.

Carlo Vercellone $(2007,24)$, another proponent of the autonomist school, argues: "The subsumption of the worker to capital becomes real when it is imposed inside the production system and no longer only outside it". Vercellone stresses that "[t]he compulsion to wage-labour is no longer merely of a monetary nature, but also of a technological nature, rendered endogenous by technical progress. In such a way, the individual labour-power of the producer, increasingly reduced to a simple living ap- 
pendage of the system of machines, 'now...refuses its services unless it has been sold to capital'" (Ibid.). The attempt to render labour as mere appendage is counterbalanced by shifts in the Fordist era to political democratisation, the welfare state and mass education and the tendency towards 'diffuse intellectuality' which produced "the crisis of the first dimension of real subsumption", entailing the "incessant struggle of wage-labourers for the re-appropriation of knowledges and the emancipation from the economic compulsion of wage labour" (Ibid., 25).

Thus, the shift from the real subsumption to the general intellect is one of a continuing process of capital's subsumption of labour, though in this instance it is the process of information technology moving to absorb the entirety of human capacity that inheres in the human brain. Yet, at the same time, it opens up the possibility for labour to reclaim knowledge and to reverse the real subsumption, indeed with the possibility at some stage to eliminate subsumption all together. This is because of a fundamental backstop in the process of real subsumption, which is precisely that the brain cannot be fully absorbed into the machinery nor reproduced within it: "[i]n the cognitive-labour-producing knowledge, the result of labour remains incorporated in the brain of the worker and is thus inseparable from her person" (Ibid., 33).

Vercellone, sees this as the logic of the Fragment on Machines, and one that foreshadows the challenge to Post-Fordism. Vercellone $(2007,28)$ reads Marx as believing that, "the deepening of the real subsumption can create certain conditions favourable to a collective reappropriation of knowledges insofar as 'living labour' is able to reconvert part of its surplus into free time". One key aspect to developing this challenge towards an emancipatory logic is the condition that this free time be converted into "the education of a diffuse intellectuality" $(2007,29)$. No wonder education has been relentlessly under attack as a public good in the most crisis ridden capitalist economies.

As soon as "[t]he principal 'fixed capital' becomes 'man himself" (Ibid.) then the imperative to capture this is intensified, returning us to the condition of the formal subsumption, "in the sense that it is based essentially on the relation of monetary dependence of wage-labourer inside the process of circulation" (Ibid., 31). In this form of capitalism then, in order to maintain its grip, capital has to act as an external force directly on the brain. It can therefore be no surprise that we have increasingly become witness to the development of, for example, affective mechanisms aimed squarely at the nervous system. Franco 'Bifo' Berardi has explored such practices as inducing new kinds of pathological relations to work. He has termed this relation 'neuro-totalitarianism' in the context of what he calls 'the soul at work'. In the book of that name Berardi tells us, in line with the broader understanding of cognitive labour, " $h i$ tech workers invest their specific competencies, creative, innovative and communicative energies in the labour process; that is, the best part of their intellectual capacities" (Berardi 2009, 78). However, while such workers are in some senses less alienated and, as we have seen, subsumed by capital, than their industrial predecessors, their distance, but at the same time monetary reliance, means that they need to be perpetually on call. When workers are called to give, they must give everything and as such "Info-workers can be seen as "neuro workers". They prepare their nervous system as an active receiving terminal for as much time as possible" a process that Berardi $(2009,90)$ compares to "the constant stress of a permanent cognitive electrocution".

In a generalised condition of cognitive electrocution that spreads out from cognitive labour into the entire social sphere, wherein social activity itself is drawn into this process of digital formal subsumption, we live in something akin to a "multilayered 
dimension of technomaya" wherein "[d]igital technology has given a power to the media that is directly acting on the mind, so that the spell of the media-sphere has wrapped itself around the psychosphere" (Berardi 2014, 6). The extent of the misery caused by this is indicated by the huge increase in mental illness and suicide that has occurred in the Post-Fordist era, "in the last 45 years suicide rates have increased by $60 \%$ world-wide" and Berardi puts this down to the fact that "An epidemic of unhappiness is spreading over the planet" because "[s]emiocapitalism is infiltrating the nervous cells of conscious organisms, inoculating them with a thanato-political rationale" (Ibid., 13).

Semiocapitalism includes the drive to capture attention that is typical of the digital platforms that have come to dominate digital life since the early 21 st century. The monetarisation of attention, in terms of both the targeting of adverting but also in the user generation of new content, can be seen as something akin to the becoming labour of the social. This expanding condition ensures that the struggle within historical materialism is now over the brain itself. For example, Google is referred to by Berardi $(2014,14)$ as "the most refined attention-draining machine" that has now been further boosted by the development of the smartphone that is "pervading every moment of the day and night". Berardi concludes by suggesting that this "manipulation of neural systems" (Ibid., 25) needs to be understood in light of the neuro-plasticity of the brain. The ability of the brain to assimilate and adapt to contextual inputs makes the brain the material end point of capital's attempts to capture it in value creating circuits, "intervening on the neural system, redirecting neural activity and reshaping synaptic pathways" (Ibid.).

\section{Conclusion: Plasticity and Determination in the Last Instance}

The moulding of the plastic brain has always been the focus of capitalism, but it has gone from being a derivative to a primary aim in the shift to post-Fordism, as Marx himself pre-empts in the Fragment on Machines. In this configuration Berardi (2014, 25) does offer some cause for hope, surmising that the neuro-plastic aspects of the brain "invites a process of sabotage and subversion of the dominant modes of mental wiring". Although Berardi's references to neuro-plasticity are fleeting there is nothing here that is unreasonable.

In essence neuroplasticity means the brain is significantly moulded by its environment and is perpetually affected and adapted to its context, "The adult brain is not only capable of changing, but it does so continuously throughout life" (Constandi 2016 , 4). But the brain is not changing passively, it is always actively filtering, modelling, reworking, and feeding back on itself. As the leading scholar in the humanities and social sciences on this topic, Catherine Malabou (2008, 13), demands regarding the plastic brain: "securing a true plasticity means insisting on knowing what it can do and not simply what it can tolerate". This is supported by the brain's 'modulational' capacity which means plasticity adds to it, "the functions of artist and instructor in freedom and autonomy to its role as sculptor", brains don't just receive information but, "have the power to form or to reform this very information" (Ibid., 24).

The need for a consciousness of plasticity to be harnessed, collectively, to reflexively take back control of the brain's own volitions, is the pivot point of the contemporary struggle against capital. Harnessing must also take account of the leaps forward in understanding pre-conscious affective aspects of the brain, but nevertheless here we can propose the brain as operating as the source of determination in the last instance - not merely another aspect of overdetermination - as would be the conclusion from earlier representations of the base/superstructure or determinism/agency 
question. These earlier incarnations may be appropriate to their times, and to their contemporary understandings of the brain, but we are now in a positon to again refresh Marx in light of changes to capitalism, and also the emerging insights of neuroscience.

To recognise the brain as determining in the last instance is not to take a pure voluntarist position, but to understand that the brain is under the immense pressures of neuro-totalitarianism inherent in the Post-Fordist economy and embedded in the dialectic of historical materialism, but also with the power to adapt, to rework and to reinvent. The prevailing condition is one in which the brain's modulational capacity is habitually concealed, repressed and nominally diverted to tasks not best served to its own thriving - but in the end it is the brain itself which is the substrata that supports the rest of the mechanism of capital.

Malabou $(2008,1)$ makes a direct analogy of brain plasticity to Marx and historical materialism, telling us: "Humans make their own brain, but they do not know that they make it". So it is we still can talk of historical materialism to the extent that the brain has become caught in a dialectic with the machinery of fixed capital. As Malabou tells us "to talk about the plasticity of the brain means to see in it not only the creator and receiver of form but also an agency of disobedience to every constituted form, a refusal to submit to a model" (Ibid., 6). For Malabou, the imperative is for us to gain consciousness of this plasticity, of its capacity. In doing so we should make sure we are not merely submitted to the logic of capital, in particular the kind of digital, flexible networked capitalism discussed above, so she asks, "What should we do so that consciousness of the brain does not purely and simply coincide with the spirit of capitalism?" (Ibid., 12). Therefore, the struggle is to gain control of consciousness, in that sense the task is as it ever was - but is now more immanent than ever given the brain's foundational importance for capital.

Berardi $(2014,27)$ talks about the need to "disentangle the autonomy of the general intellect from its neuro-totalitarian jail". This seems to me like the best call to arms for a Marxism of the 21st century and a suitable renewal of the project that was born with Marx himself 200 years ago - so to answer my earlier question, we must marshal our collective brains to bring about change, but this must instigate a change in the mode and relation of production that is currently parasitic on the brain, or ultimately it will be a superficial and fruitless enterprise.

\section{References}

Balibar, Étienne. 2017. The Philosophy of Marx. London: Verso.

Berardi, Franco "Bifo". 2014. Technomaya Goog-Colonization of Experience and Neuroplastic Alternative. Los Angeles: Semiotext(e).

Berardi, Franco "Bifo". 2009. The Soul at Work: From Alienation to Autonomy. Los Angeles, CA: Semiotext(e).

Callinicos, Alex. 2004. Making History: Agency Structure and Change in Social Theory. Leiden: Brill. 2nd Edition.

Constandi, Moheb. 2016. Neuroplasticity. Cambridge, MA: MIT Press.

Fromm, Erich. 2004. Marx's Concept of Man. London: Continuum.

Geras, Norman. 1983. Marx and Human Nature, Refutation of a Legend. London: Verso.

Hall, Stuart. 2016. Marxist Structuralism. In Cultural Studies 1983, edited by Jennifer Daryl Slack and Lawrence Grossberg. Durham: Duke University Press.

Hall, Stuart. 1977. Re-Thinking the 'Base-and-Superstructure' Metaphor. In Class, Hegemony, Party, edited by Jon Bloomfield, 43-72. London: Lawrence \& Wishart.

Hill, Amelia. 2018. Seven in 10 UK Workers are 'Chronically Broke', Study Finds." The Guardian. January 25. Accessed January 25, 2018. 
https://www.theguardian.com/money/2018/jan/25/uk-workers-chronically-broke-studyeconomic-insecurity.

Lukács, Georg. 1971. History and Class Consciousness. Cambridge, MA: MIT Press.

Malabou, Catherine. 2008. What Should We Do with Our Brain? New York: Fordham University Press.

Marx, Karl. 1987. A Contribution to a Critique of Political Economy. In Marx-Engels-Collected Works (MECW), Volume 29. London: Lawrence and Wishart.

Marx, Karl. 1979. The Eighteenth Brumaire of Louis Bonaparte. In Marx-Engels-Collected Works (MECW), Volume 11, 99-197. London: Lawrence and Wishart.

Marx, Karl. 1973. Grundrisse. London: Penguin.

Meiksins Wood, Ellen. 1995. Democracy Against Capitalism, Renewing Historical Materialism. Cambridge: Cambridge University Press.

Molyneux, John. 1995. Is Marxism Deterministic. International Socialism Journal 68. Accessed January 30, 2018. https://www.marxists.org/history/etol/writers/molyneux/1995/xx/determin.htm

Stalin, Joseph. 1938. Dialectical and Historical Materialism. Accessed January 11, 2018. https://www.marxists.org/reference/archive/stalin/works/1938/09.htm.

Vercellone, Carlo. 2007. From Formal Subsumption to General Intellect: Elements for a Marxist Reading of the Thesis of Cognitive Capitalism. Historical Materialism 15: 13-36.

Virno, Paolo. n.d. General Intellect. Generation Online. Accessed Jan 24, 2018. http://www.generation-online.org/p/fpvirno10.htm.

Williams, Raymond. 2005. Culture and Materialism. London: Verso.

Wright, Erik Olin, Andrew Levine, and Elliott Sober. 1992. Reconstructing Marxism: Essays on Explanation and the Theory of History. London: Verso.

\footnotetext{
About the Author

Joss Hands

Joss Hands is Senior Lecturer in Media and Cultural Studies at Newcastle University. He is author of @ is For Activism: Dissent, Resistance and Rebellion in a Digital Culture (2011) and Gadget Consciousness: Thought, Will and Action in the Age of Social Media (forthcoming with Pluto Press in 2019). He is an editor of the Digital Barricades book series with Pluto Press.
} 